\title{
RECORD THE TRANSCRIPT OF STUDENT ACTIVITY IN HIGHER EDUCATION BASED ON BLOCKCHAIN TECHNOLOGY
}

\author{
Meyliana ${ }^{1}$, Yakob Utama Chandra ${ }^{1}$, Cadelina Cassandra ${ }^{1}$, Surjandy $^{1}$, \\ Henry Antonius Eka Widjaja ${ }^{1}$, Erick Fernando ${ }^{1}$ and Harjanto Prabowo ${ }^{2}$ \\ ${ }^{1}$ Information Systems Department, School of Information Systems, Bina Nusantara University Jakarta, Indonesia, 11480 \\ ${ }^{2}$ Computer Science Department, BINUS Graduate Program - Doctor of Computer Science, Bina Nusantara University \\ Jakarta, Indonesia, 11480
}

\begin{abstract}
Apart from the core competency, learning in the organization also brings students opportunities to improve their soft skills. Good soft skills can help students when working in a company with many people. Students can get soft skills by participating in various non-academic activities such as new student orientation, Student organization, seminar, and workshop. For every non-academic activity participated by students, they will get points and recorded in Student Academic Transcript (SAT). SAT is an integral part of a diploma certificate. The research method used in this research is a user-centered design to build an education value chain model for recording student activity transcripts based on blockchain technology. Blockchain technology is used to ensure data validity, reliability, and integrity for all student non-academic activities.
\end{abstract}

\section{KEYWORDS}

Blockchain, Higher Education, Student, Transcript, Activity, Point

\section{INTRODUCTION}

Learning in university is carried out by learning the hard skill (core competency) according to the major and leaning the soft skill. Soft skill learning is currently considered very important, especially in the industrial era of 4.0. The World Economic Forum in 2019 has predicted that several skills will grow and will disappear in 2022 (5 things to know about the future of jobs | World Economic Forum, no date). Some skills such as analytical thinking and innovation, active and strategy learning, creativity, originality, and initiative, etc., will still exist and needed in this era, while some skills such as manual dexterity, endurance, and precision, memory, verbal, auditory and spatial abilities, management of financial, material resources, etc. will be no longer needed because they can be replaced by technology / robots. This situation needs to be responded quickly by universities in providing students with the suitable soft skills according to industry needs (Ekaterina, Anastasya and Ksenya, 2015). Problem solving is one soft skill that needed the most by industries. Problem solving is not instant, it must be trained continuously, because of that, this skill must be taught in both academic and non-academic learning processes from the first semester. More creativity is needed to improve students' ability in solving problems (Škèrienè and Jucevičienè, 2020).

Apart from problem solving, creative thinking is also important because creative thinking makes students have high adaptive abilities in various situations. In addition, creative thinking can produce unique outcomes and it can be a differentiator from its competitors. This will be an added value for students (Cheng, 2019). Students also need to improve their self-management. Self-management can be formed from a student mindset while study so they can explore and manage themselves, this soft skill can give students the ability to become an intrapreneur or entrepreneur, and be able to face various kinds of obstacles (Almeida, Daniel and Figueiredo, 2019). 
Humans are social creatures who cannot live individually, so they really need social skills to interact with others. One skill that is very important to interact with other people is a communication skill. Humans are highly valued based on the way they communicate with others.

With good communication skills, students can "sell themselves" which has a positive connotation. Other people can consider the good potential of the students based on the way they communicate. Communication skills must be trained from students entering the university until they graduate, both orally and writing (Tseng, Yi and Yeh, 2019). The implementation of hard skill and soft skill learning is integrated into the academic curriculum document, so for every learning carried out by students, there is a guarantee that students get hard skill and soft skill learning simultaneously. Evidence of hard skills learning outcomes is recorded in student transcripts, while evidence of soft skills learning outcomes is recorded in student activity transcripts (Rebele and St. Pierre, 2019).

Learning activities in university must be able to answer the challenges that occur in society. The participation of the community, including the industry, in learning activities is expected. The active involvement of the community in learning activities will significantly improve students' hard skills and soft skills (Singh Dubey and Tiwari, 2020). The challenge from the community can be a mini case in higher education $(\mathrm{Ng}, 2020)$.

To maintain data validity and data integrity in increasing industry and public trust in universities, it is necessary to have technology that can provide the assurance of data security to ensure the record of non-academic learning activities and points are valid recorded in the student activity transcript. The number of points earned by students is confirmed according to the activities carried out by students (Bongiovanni, 2019).

Blockchain technology can be a solution in recording student activity points and providing the data validity and integrity. Thus, companies or organizations will trust the results that have been made on blockchain technology. Companies or organizations will see through the student activity transcript for the data validity of non-academic learning activities held by university (Grech and Camilleri, 2017).

The research question of this research is how to build a blockchain model for university to maintain data integrity in recording student activity into student activity transcript?

This research used a qualitative approach, and the research method is using a user-centered design framework to answer the research questions. The result of this research is the education value chain model for the process of recording student activity transcript based on blockchain technology, which is suitable for business processes in university, starting from the student registration for non-academic learning activities in universities.

\section{LITERATURE REVIEW}

\subsection{Education Value Chain}

Students take teaching and learning processes in both intra-curricular and extra-curricular activities. Intra-curricular is an academic learning activity followed by students and lecturers and is managed by the department at university. While extra-curricular is a non-academic learning activity followed by students and is managed by student activity unit.

Exhibit in figure 1, the value chain starts with prospective students entering the university through admission process. Prospective students will take the entrance test. If the result is accepted, the prospective students will become students and take part in intra-curricular and extra-curricular activities. 


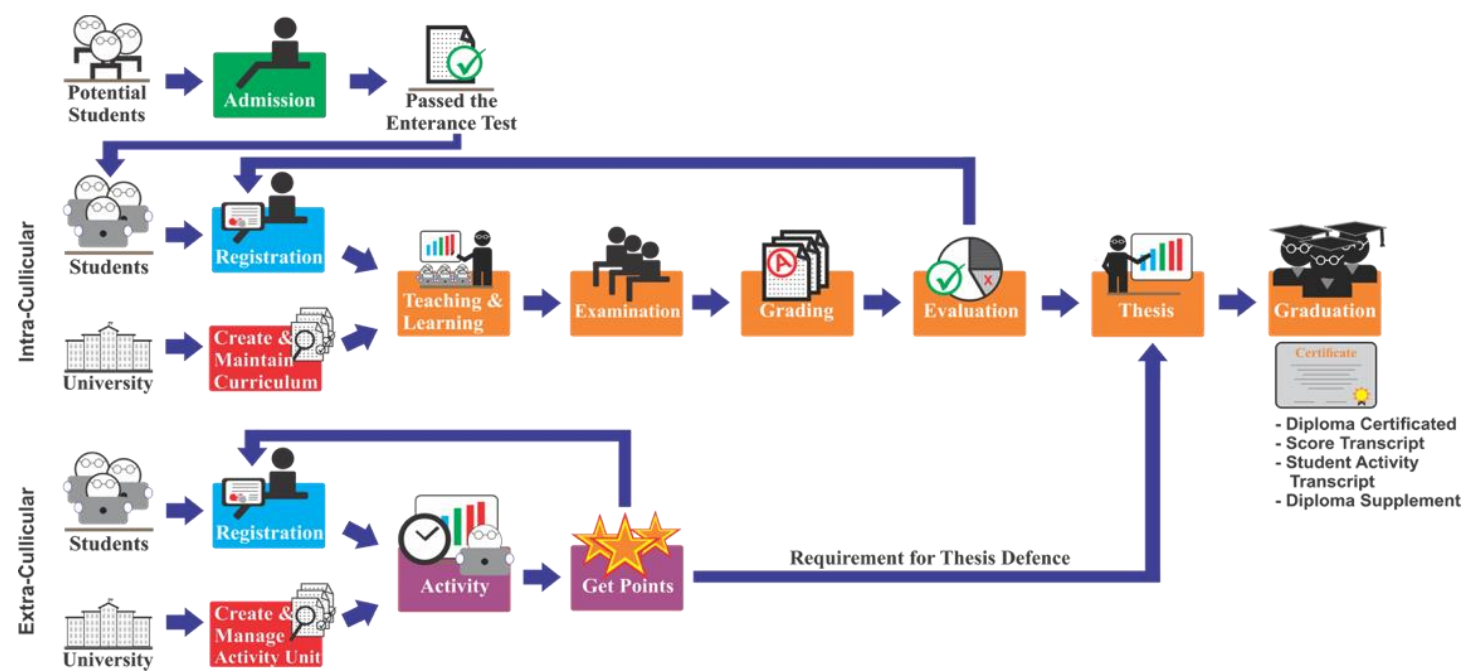

Figure 1. Education Value Chain (Meyliana et al., 2019)

Intra-curricular activities or academic activities begin from the university create and maintain curricula in each department. Students register for each lecture for every semester and follow the teaching and learning process with lecturer and laboratory staff.

Students will take the exam twice in each semester (mid exam and final exam) to determine their comprehension on the course. After students take the exam, they will receive the exam and assignment scores. After that, the grading and evaluation process will be carried out for these students. This process will be repeated until students enter the final semester and take the thesis course. One of the requirements for students to be able to take the thesis defense is students must take part in extra-curricular activities to earned points. These points will be recorded in the student activity transcript. After student passed their thesis defense and graduate, student will get the diploma certificate, transcript score, student activity transcript, and diploma supplements (Meyliana et al., 2019).

Student must also take extra-curricular learning activities. Students can register for activities organized by the student activity unit. The attendance and participation will be verified, and the points will be given to the students. These points will be collected and become a requirement for the thesis defense. The standard amount of point is determined by the university (Meyliana et al., 2020) (Chandra et al., 2019).

\subsection{Student Activity Transcript}

Non-academic learning activities will increase student soft skills. The points given to the student for their participation need to be managed and recorded properly. This recording process is very important because the data recorded is evidence of non-academic learning activities. It will be recorded in student activity transcript (SAT) (Meyliana et al., 2019).

\subsection{Blockchain in Education}

Currently, not many blockchain research for university has been discussed, because blockchain is generally implemented in companies for finance and data security (Singh and Singh, 2016).

Blockchain is possible to be implemented in various fields after smart contracts was found, all business processes can be recorded into blockchain technology and this implementation ensures data integrity and data security. The capability of blockchain such as unchangeable, undeletable, and not easy be manipulated, makes Blockchain easily detect diplomas or official university documents that require data verification and authenticity (Devecchi et al., 2017)(Palma et al., 2019). 


\section{RESEARCH METHODOLOGY}

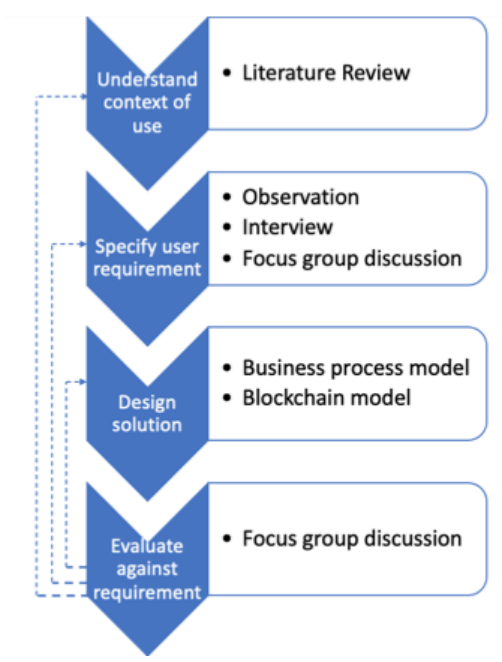

Figure 2. Research Methodology (User-Centered Design)

This research used User Centered Design Method (What is User Centered Design? | Interaction Design Foundation (IxDF), no date). Exhibit in figure 2 shows the initial stage starts from understanding the context of use. In this case, the method used is to literature study about student activity in universities and how blockchain technology can maintain data integrity in universities related to that student activity.

After literature study, the research was continued by specifying user requirements by doing observations, interviews, and focus group discussions. Regarding student activity data that needs to be maintained by blockchain technology, an observation is done to see how the process from the beginning to the end until the student activity data can be recorded to student activity transcript. In addition, interviews and focus group discussions was conducted to confirm the processes from several universities so the results could be generalized to facilitate implementation in many universities.

The next stage is the design solution. At this stage, the education value chain model based on blockchain technology was designed focuses on certain business processes and according to focus group discussions result, especially on recording student activity transcript data.

The model was evaluated on the next stage. Focus group discussion was conducted again to get the feedback. The results of this focus group discussion also validate the education value chain model based on blockchain technology.

\section{RESULT AND DISCUSSION}

This research focuses on extra-curricular activities or non-academic learning activities in university, starting from the activity created and managed Student Activity Unit. Students can register and take part on the activities. The student participation will be rewarded as points and student can collect them. These points are recorded into a student activity transcript which will be distributed to students along with diploma certificate and academic transcripts when students graduated from the university. This process can be seen in figure 3 . 


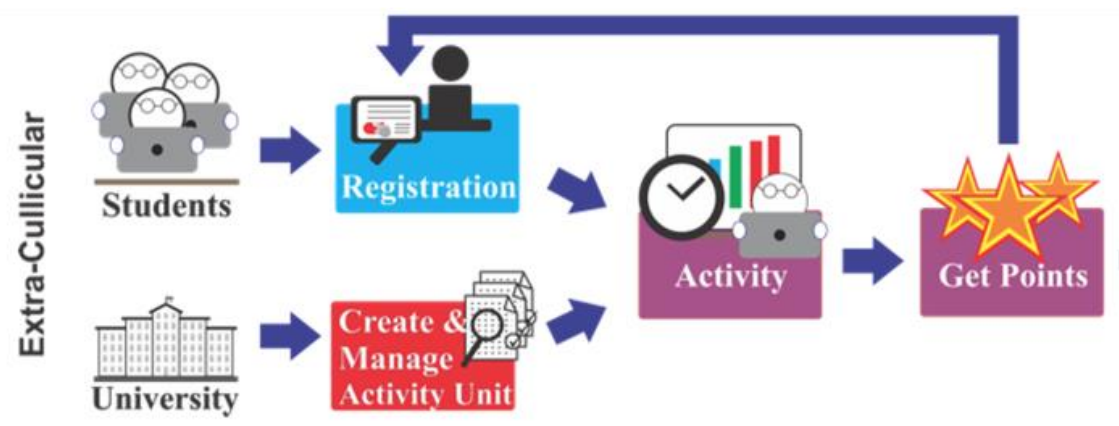

Figure 3. Focus of Research (Meyliana et al., 2019)

Non-academic learning activities aim to improve soft skills and provide real experiences for students. Figure 4 shows a detailed business process of recording student activity transcript using blockchain technology. Student activity units / departments / universities can propose making non-academic learning activities by submitting activity proposals to the student affairs section. If the activity proposal is approved, the student activity unit / department / university can create activities in the event management system and input the event name, description, location, time, and how many SAT points can be earned by student. This data is stored in a blockchain technology database. Then the student activity unit / department / university will publish the event on social media platforms and university digital media.

After published, students can register on the application provided by the committee. If the event is a paid event, students are asked to make payments to the university account number. In this case, the payment is received by the university finance unit. The finance unit then confirms the payment to the event organizer. After Student activity units / departments / universities receive payment, the unit will confirm and validate the registration and payment (if any) from student and send the proof of registration and payment (if any) to the student. Activities to validate registration and payment (if any) from students are also stored in the blockchain technology database.

On the day of the event, students will attend the event and give the proof of registration and payment. The committee will input the evidence into event management system and add the SAT points. Student attendance data SAT points are stored in the blockchain technology database. The report will be given to the student. This will continue to be repeated until students reach the minimum number of points according to the standard of university. If the student has passed the thesis defense, the student grading unit will print the student activity transcript which will be distributed to students along with diploma certificate and academic transcripts. From the business processes described above, there are four main activities for data recording in blockchain technology databases, they are:

a. Record event

The data recorded is event code, event name, description, event type, time, location, event organizer name, target of participant, and amount of SAT Points. Event type is the scale of the event (international / national / local).

b. Record registration and payment from student

In this section, the data recorded is the student name, student ID, student major, student campus location, event code, payment type (if any), payment amount (if any).

c. Record student data and SAT Point

In this section, the data recorded is student name, student ID, student major, student campus location, event code, event name, description, event type, time, location, SAT points earned, SAT points cumulative.

d. Record student activity transcript

In this section, the data recorded is student name, student ID, student major, event code, event name, along with each point earned. 


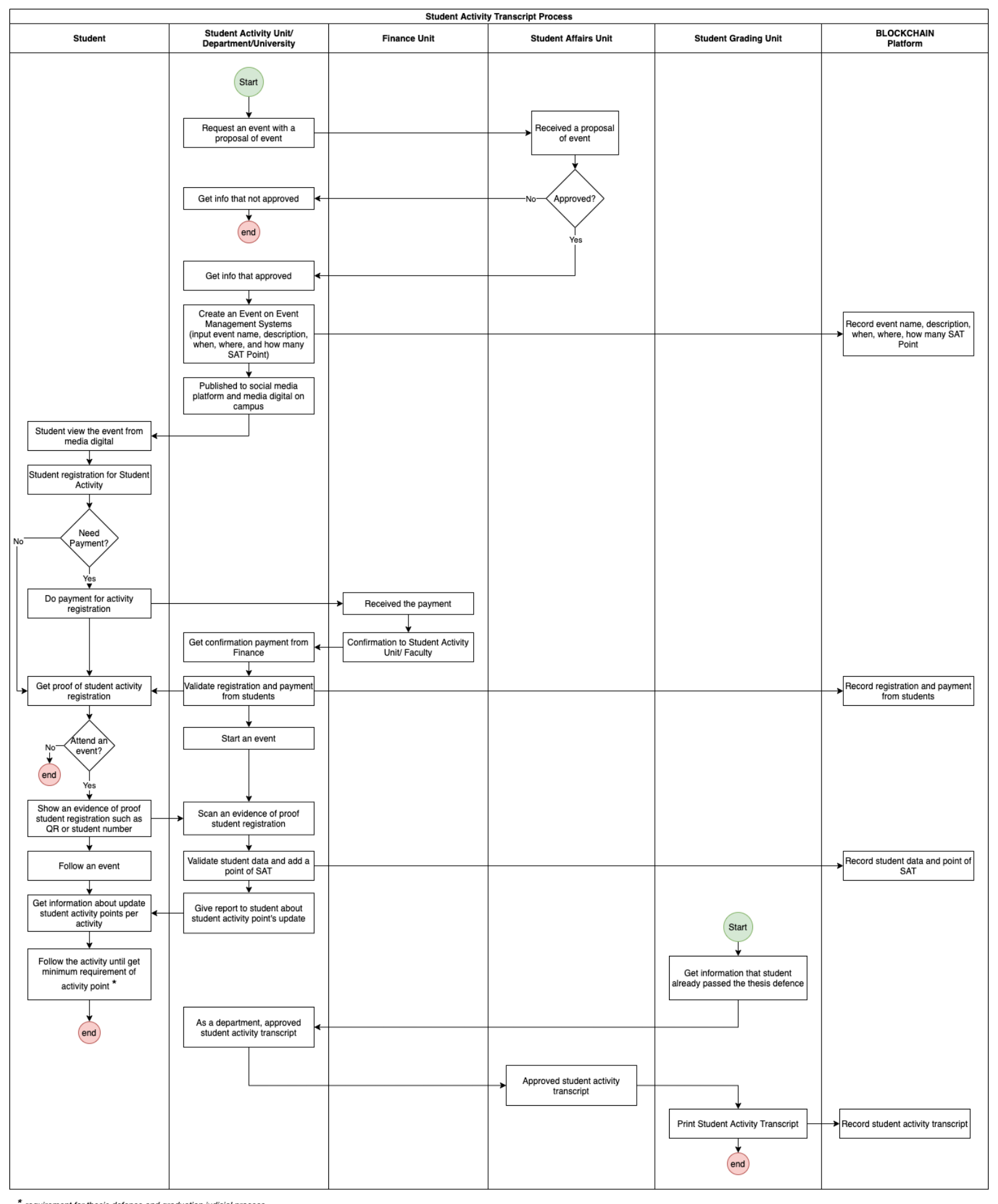

Figure 4. Business Process Model with Blockchain 


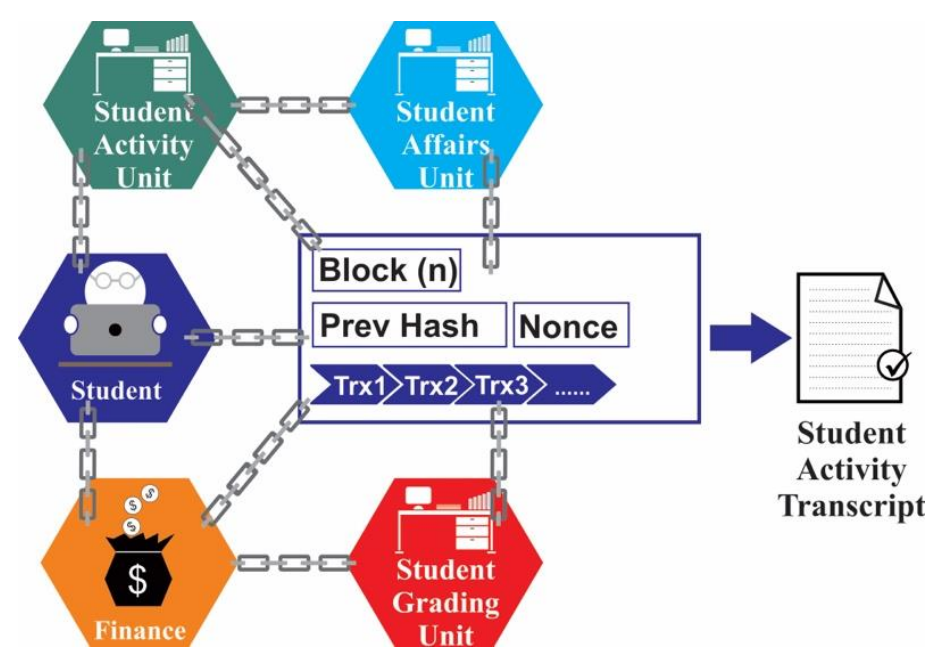

Figure 5. Transaction Illustration of Education Value Chain Model for student activity transcript record

Exhibit in Figure 5 is an illustration of transactions from the education value chain model for recording student activity transcript based on blockchain technology. The part involved in this transaction are student, student activity unit / department / university, student affairs unit, finance unit, and student grading unit. All parts are integrated with each other to produce correct and valid data points thus the point record into the student activity transcript has good data validity.

\section{CONCLUSION}

The process of student non-academic learning activities in university produces points that can be collected cumulatively as a standard for achieving soft skills for a student. All data points collected by students are recorded into a student activity transcript and recorded in blockchain technology.

The implementation of blockchain technology provides benefits and data integrity. It will increase public dan industry for the quality of the graduates. This is consistent with the characteristics of blockchain technology which makes data undeletable, unchangeable, not easy to be manipulated, peer to peer, and distributed. If there is data adjustment, new data can only be added and linked to the old data, the previous data cannot be replaced.

\section{ACKNOWLEDGEMENT}

This work is supported by the Directorate General of Strengthening for Research and Development, Ministry of Research, Technology, and Higher Education, Republic of Indonesia as a part of Penelitian Terapan Unggulan Perguruan Tinggi Research Grant to Binus University entitled "Implementasi Blockchain Platform untuk Menciptakan "Good Governance" pada Perguruan Tinggi" or "The Implementation of Blockchain Platform to Create "Good Governance" in Higher Education" with contract number: 12/AKM/PNT/2019 and contract date: 27 March 2019.

\section{REFERENCES}

5 things to know about the future of jobs | World Economic Forum (no date). Available at: https://www.weforum.org/agenda/2018/09/future-of-jobs-2018-things-to-know/ (Accessed: 25 November 2020).

Almeida, J., Daniel, A. D. and Figueiredo, C. (2019) 'The future of management education: The role of entrepreneurship education and junior enterprises', International Journal of Management Education. Elsevier, (November 2018), p. 100318. doi: 10.1016/j.ijme.2019.100318. 
Bongiovanni, I. (2019) 'The least secure places in the universe? A systematic literature review on information security management in higher education', Computers and Security. Elsevier Ltd, 86, pp. 350-357. doi: 10.1016/j.cose.2019.07.003.

Chandra, Y. U. et al. (2019) 'Smart E-badge for Student Activities in Smart Campus', Proceeding - 2019 International Conference on ICT for Smart Society: Innovation and Transformation Toward Smart Region, ICISS 2019. doi: 10.1109/ICISS48059.2019.8969806.

Cheng, V. M. Y. (2019) 'Developing individual creativity for environmental sustainability: Using an everyday theme in higher education', Thinking Skills and Creativity. Elsevier, 33(April 2018), p. 100567. doi: $10.1016 /$ j.tsc.2019.05.001.

Devecchi, C. et al. (2017) 'Blockchain Educational Passport Blockchain Educational Passport: Decentralised Learning Ledger (DLL) Preceding white papers Proof-of-Concept: Authors', Development Heads: Sajin Abdu (Technology), (Dll). Available at: https://github.com/seratio/whitepaper\%0Ahttps://issuu.com/seratio/docs/social_value_and_ intangibles_review_3109c1666edf2\%0Ahttp://mypad.northampton.ac.uk\%0Ahttp://eepurl.com/cCQgJv\%0Ahttp://e epurl.com/cnrY7L\%0Awww.cceg.org.uk/lab\%0Ahttp://blockchain.sera.

Ekaterina, G., Anastasya, B. and Ksenya, G. (2015) 'Sociocultural Competence Training in Higher Engineering Education: The Role of Gaming Simulation', Procedia - Social and Behavioral Sciences. Elsevier B.V., 166(d), pp. 339-343. doi: 10.1016/j.sbspro.2014.12.533.

Grech, A. and Camilleri, A. F. (2017) 'Blockchain in Education', JRC Science for Policy Report. doi: 10.2760/60649.

Meyliana et al. (2020) 'A Proposed Model of Secure Academic Transcript Records with Blockchain Technology in Higher Education', (Conrist 2019), pp. 172-177. doi: 10.5220/0009907401720177.

Meyliana, M. et al. (2019) 'Defying the Certification Diploma Forgery with Blockchain Platform: A Proposed Model', in Proceedings of the International Conferences ICT, Society, and Human Beings 2019; Connected Smart Cities 2019; and Web Based Communities and Social Media 2019. IADIS Press, pp. 63-71. doi: 10.33965/ict2019_201908L008.

Ng, L. K. (2020) 'The perceived importance of soft (service) skills in nursing care: A research study', Nurse Education Today. Elsevier, 85(April 2019), p. 104302. doi: 10.1016/j.nedt.2019.104302.

Palma, L. M. et al. (2019) 'Blockchain and smart contracts for higher education registry in Brazil', International Journal of Network Management, (June 2018), pp. 1-21. doi: 10.1002/nem.2061.

Rebele, J. E. and St. Pierre, E. K. (2019) 'A commentary on learning objectives for accounting education programs: The importance of soft skills and technical knowledge', Journal of Accounting Education. Elsevier Ltd, 48, pp. 71-79. doi: 10.1016/j.jaccedu.2019.07.002.

Singh Dubey, R. and Tiwari, V. (2020) 'Operationalisation of soft skill attributes and determining the existing gap in novice ICT professionals', International Journal of Information Management. Elsevier, 50(May 2019), pp. 375-386. doi: 10.1016/j.ijinfomgt.2019.09.006.

Singh, S. and Singh, N. (2016) 'Blockchain: Future of financial and cyber security', Proceedings of the 2016 2nd International Conference on Contemporary Computing and Informatics, IC3I 2016, pp. $463-467$. doi: 10.1109/IC3I.2016.7918009.

Škèrienè, S. and Jucevičienė, P. (2020) 'Problem solving through values: A challenge for thinking and capability development', Thinking Skills and Creativity. Elsevier, 37(May), p. 100694. doi: 10.1016/j.tsc.2020.100694.

Tseng, H., Yi, X. and Yeh, H. Te (2019) Learning-related soft skills among online business students in higher education: Grade level and managerial role differences in self-regulation, motivation, and social skill, Computers in Human Behavior. Elsevier B.V. doi: 10.1016/j.chb.2018.11.035.

What is User Centered Design? | Interaction Design Foundation (IxDF) (no date). Available at: https://www.interactiondesign.org/literature/topics/user-centered-design (Accessed: 13 November 2020). 